\title{
IDENTIFIKASI BAKTERI AEROB DI UDARA RUANG OPERASI INSTALASI BEDAH SENTRAL (IBS) RSUP ROF. DR. R. D. KANDOU MANADO
}

\author{
${ }^{1}$ Billy V. Palawe \\ ${ }^{2}$ Constantien Kountul \\ ${ }^{3}$ Olivia Waworuntu
}

\author{
${ }^{1}$ Kandidat Skripsi Fakultas Kedokteran Universitas Sam Ratulangi Manado \\ ${ }^{2}$ Bagian Mikrobiologi Fakultas Kedokteran Universitas Sam Ratulangi Manado \\ Email: billyvallent@yahoo.com
}

\begin{abstract}
Air is not a medium where microbes grow, but it is a carrier of particulate matters, such as dust and water droplets which are very probably loaded with microbes. And the most of bacteria that live in the air of the hospitals room environment consist of Bacillus bacteria, E.coli, Staphylococcus, Streptococcus, Pseudemonas, also fungi which is Aspergillus species. Objective: To determine the existence of aerobic bacteria and others species in the operating room of air Installation Central Surgery (IBS). Prof. Dr. R. D. Kandou Manado. Methods: It is a prospective descriptive study to get an overview of the bacteria in the air of aerobic Central Surgery Installation operating room (IBS) Prof. Dr. R. D. Kandou Manado. Results: Staphylococcus Albus bacteria found in Nutrient Agar media (NA) And Blood Agar (AD), while Bacillus subtilis found in Blood Agar media (AD).Conclusion: In the air of Central Surgery Installation operations room (IBS) Prof. Dr. RD Kandou Manado, based on the result shows the high number of aerobic bacteria.
\end{abstract}

Keywords: aerobic bacteria,in the operations room air.

\begin{abstract}
Abstrak: Udara bukan merupakan medium tempat mikroba tumbuh, tetapi merupakan pembawa bahan partikulat, debu, dan tetesan air yang semuanya sangat mungkin dimuati mikroba. Mikroorganisme yang paling banyak berkeliaran di udara lingkungan rumah sakit adalah bakteri Bacillus, E.coli, Staphylococcus, Streptococcus, Pseudemonas, dan spesies jamur seperti Aspergillus. Tujuan: Mengetahui adanya bakteri aerob dan jenis lainnya di udara ruang operasi Instalasi Bedah Sentral (IBS) RSUP. Prof. Dr. R. D. Kandou Manado. Metode: Penelitian ini bersifat penelitian deskriptif prospektif yaitu untuk mendapatkan gambaran bakteri aeorob di udara ruang operasi Instalasi Bedah Sentral (IBS) RSUP Prof. Dr. R. D. Kandou Manado. Hasil: Staphylococcus Albus ditemukan di media spesifik Agar Nutrientt (NA) dan Agar Darah (AD) sedangkan Bacillus Subtilis ditemukan di media spesifik Agar Darah (AD). Simpulan: Udara diruang operasi Instalasi Bedah Sentral (IBS) RSUP Prof. Dr.R. D. Kandou Manado, menunjukan masih tingginya jumlah angka bakteri aerob.
\end{abstract}

Kata kunci: bakteri aerob, udara diruang operasi.

Rumah sakit adalah bangunan yang penuh dengan sumber penyakit dan sumber infeksi. Kuman penyakit ini dapat hidup dan berkembang di lingkungan rumah sakit misalnya pada kamar operasi dan ruang perawatan. Kuman tersebut dapat berada dimana-mana seperti; udara, air, lantai, makanan dan benda-benda medis maupun non medis. Oleh karena itu harus diperhatikan dan dikendalikan kemungkinan-kemungkinan terjadinya penyebaran infeksi secara langsung, tidak langsung, 
udara (airborne infection), dan vector borne diseases atau melalui vector (perantara). ${ }^{1}$

Hal pertama yang harus diperhatikan adalah pengaplikasian sistem tata udara pada bangunan rumah sakit harus benar, terutama untuk ruangan-ruangan khusus seperti di ruang operasi/bedah, ruang Isolasi dan lain-lain diperlukan pengaturan temperatur, kelembaban udara relatif, kebersihan cara filtrasi dan udara ventilasinya, tekanan ruangan yang positif dan negatif, perbedaan tekanan antar ruang fungsi tertentu dengan ruang disebelahnya, dan distribusi udara didalam ruangan untuk meminimalkan sumber penyakit agar tidak menyebar ke udara (airborne) yang memperbesar kemungkinan terjadinya penularan penyakit. ${ }^{1-3}$

Ruang operasi merupakan ruangan yang berpotensi tinggi menyebabkan infeksi nosokomial di rumah sakit terutama infeksi luka operasi.Lingkungan ruang operasi beresiko tinggi yang bisa menjadi tempat yang mudah menularkan infeksi dari dan ke penderita, karena di ruang operasi ini terjadi pemajanan jaringan tubuh. Penularan infeksi yang terjadi tergantung dari jumlah kuman, kerentanan individu waktu kontak, virulensi agen infeksi, dan perbandingan terbalik dengan daya tahan tubuh. Sumber infeksi juga dapat berasal dari personel kamar operasi, alat dan bahan penunjang pembedahan, lingkungan pembedahan dan pasien yang akan dibedah., ${ }^{1,3-5}$

Di ruang operasi, staf dan pasien merupakan sumber utama bakteri yang ditularkan melalui udara.Sewaktu berjalan, dilepaskan skuama kulit, dimana kira-kira sekitar 10\% mengandung kelompok bakteri yang jumlahnya dapat meyebabkan infeksi. Bakteri biasanya mendarat di duk dan dipindahkan ke luka terbuka melalui alatalat bedah atau tangan operasional. ${ }^{1,3-5}$

Beberapa hal yang perlu diperhatikan selama penggunaan alat-alat operasi adalah jenis, jumlah, kebersihan atau sterilisasi, tata letak dan kondisi alat-alat operasi yang digunakan harus dipertahankan sterilisasinya sampai pelaksanaan operasi selesai dan segera dibersihkan setelah selesai digunakan. Proses sterilisasi tersebut dapat dilakukan dengan uap panas, larutan kimia, pemanasan kering atau metode gas. ${ }^{1,4,6}$

Timbulnya infeksi nosokomial merupakan penyebab utama peningkatan mortalitas dan morbiditas pada penderita yang di rumah-sakitkan yang disebabkan oleh mikroba patogen dan bersifat dinamis. ${ }^{7-9}$

Pencegahan dan pengendalian terjadinya infeksi nosokomial pada prinsipnya adalah mengandung unsur untuk melakukan eliminasi agen dan reservior, menghambat penularan infeksi, dan melindungi host dari infeksi. Ruang operasi yang kurang terjaga ke aseptisannya akan berdampak pada infeksi luka operasi pada pasien yang bisa diketahui pasca operasi. $4,7,8,10$

Flora mikroba yang ada di udara bersifat sementara dan beragam. Udara bukan merupakan medium tempat mikroba tumbuh, tetapi merupakan pembawa bahan partikulat, debu, dan tetesan air yang semuanya sangat mungkin dimuati mikroba. Jumlah dan tipe mikroba yang mencemari udara ditentukan oleh sumber pencemaran di dalam lingkungan, misalnya dari saluran pernafasan manusia disemprotkan melalui batuk atau bersin. ${ }^{11,12}$

Mikroorganisme yang paling banyak berkeliaran di udara lingkungan rumah sakit adalah bakteri dan jamur. Suatu benda/ perlengkapan operasi, substrat atau tangan petugas rumah sakit yang terkontaminasi, jasad-jasad renik kontaminan antara lain bakteri seperti Bacillus, E. coli, Staphylococcus, Streptococcus, Pseudomonas, dan spesies jamur seperti Aspergillus. ${ }^{11-13}$

\section{METODE PENELITIAN}

Penelitian ini menggunakan metode deskriptif prospektif untuk mendapatkan gambaran bakteri aeorob di udara ruang operasi Instalasi Bedah Sentral (IBS) RSUP Prof. Dr. R. D. Kandou Manado. Pengambilan sampel penelitian diambil di 4 ruang operasi Instalasi Bedah Sentral (IBS) RSUP Prof. Dr. R. D. Kandou Manado. Pemeriksaan sampel dilakukan di laboratorium Mikrobiologi RSUP Prof. Dr. R. D. Kandou Manado. 
Subjek penelitian ialah 4 ruang operasi Instalasi Bedah Sentral (IBS) RSUP Prof. Dr. R. D. Kandou Manado. Objek penelitian ialah udara di ruang operasi Instalasi Bedah Sentral (IBS) RSUP Prof. Dr. R. D. Kandou Manado.

Variabel penelitian dibedakan menjadi variabel bebas, variabel tergantung, dan variabel perantara. Definisi operasional yaitu sebagai berikut:

1. Bakteri aerob adalah Organisme aerobik atau aerob adalah organisme yang melakukan metabolisme dengan bantuan oksigen. Aerob, dalam proses dikenal sebagai respirasi sel, menggunakan oksigen untuk mengoksidasi substrat (sebagai contoh gula dan lemak) untuk memperoleh energi. ${ }^{11-13}$

2. Ruang operasi adalah suatu unit khusus di rumah sakit, dan tempat untuk melakukan tindakan pembedahan, baik elektif maupun akut, yang membutuhkan keadaan suci hama (steril). Daerah ini merupakan ruang yang berpotensi tinggi menyebabkan infeksi nosokomial di rumah sakit terutama inefeksi lika operasi. $^{3,15,16}$

3. Udara di ruang operasi ialah sampel yang diambil untuk diidentifikasi ada atau tidaknya bakteri. "Settled Down Plate" adalah teknik atau cara pengambilan sampel contoh udara.

\section{CARA KERJA}

Pengambilan sampel udara dilakukan dengan cara "Settled Down Plate" yang menggunakan media Agar Darah, Agar Nutrient dan Agar MacConkey dalam cawan petri yang diletakan di sekitar meja operasi/tempat tidur pasien. Ada 4 ruang/kamar operasi di Instalasi Bedah Sentral (IBS) yang masing-masing diambil sampel udaranya sesaat sebelum dan sesudah operasi. 1 Media spesifik Agar Darah (AD), 1 Agar Nutrient (NA) dan 1 Agar MacConkey diletakan di sekitar meja operasi di setiap ruangan. Media dibuka selama 10 - 30 menit dalam ruang operasi, setelah selesai ditutup. Untuk perjalanan ke ruang operasi Instalasi Bedah Sentral (IBS) maupun perjalanan kembali ke laboratorium mikrobiologi sampel ditempatkan dalam boks berisi es.

Pemeriksaan sampel dilakukan dengan cara isolasi, identifikasi, dan pewarnaan Gram.

\section{HASIL PENELITIAN DAN BAHASAN}

Pengambilan sampel berupa udara dilakukan sesaat sebelum dan sesudah operasi di ruang operasi Instalasi Bedah Sentral (IBS) RSUP Prof. Dr. R. D. Kandou Manado.

Pada penelitian ini digunakan 3 media spesifik dengan jumlah yang sama yang masing-masing Agar Nutrien (33,33\%), Agar Darah (33,33\%), Agar MacConkey (33,33\%).

Tabel 1. Distribusi Sampel Menurut Media Spesifik

\begin{tabular}{lcc}
\hline Media Spesifik & Jumlah Media & $\mathbf{( \% )}$ \\
\hline Agar Nutrient (NA) & 8 & 33,33 \\
Agar Darah (AD) & 8 & 33,33 \\
Agar MacConkey & 8 & 33,33 \\
\hline Jumlah & 24 & 100 \\
\hline
\end{tabular}

Tabel 2. Distribusi Sampel Menurut Lokasi

\begin{tabular}{lcccc}
\hline Sebelum Operasi & Ruang A & Ruang B & Ruang C & Ruang D \\
\hline \multirow{5}{*}{ Sesudah Operasi } & $1 \mathrm{NA}$ & $1 \mathrm{NA}$ & $1 \mathrm{NA}$ & $1 \mathrm{NA}$ \\
& $1 \mathrm{AD}$ & $1 \mathrm{AD}$ & $1 \mathrm{AD}$ & $1 \mathrm{AD}$ \\
& $1 \mathrm{MC}$ & $1 \mathrm{MC}$ & $1 \mathrm{MC}$ & $1 \mathrm{MC}$ \\
& $1 \mathrm{NA}$ & $1 \mathrm{NA}$ & $1 \mathrm{NA}$ & $1 \mathrm{NA}$ \\
Jumlah & $1 \mathrm{AD}$ & $1 \mathrm{AD}$ & $1 \mathrm{AD}$ & $1 \mathrm{AD}$ \\
& $1 \mathrm{MC}$ & $1 \mathrm{MC}$ & $1 \mathrm{MC}$ & $1 \mathrm{MC}$ \\
& $6 \mathrm{Media}$ & $6 \mathrm{Media}$ & $6 \mathrm{Media}$ & $6 \mathrm{Media}$ \\
\hline
\end{tabular}


IDENTIFIKASI KUMAN/ HASIL aerob pada 5 media spesifik Agar Nutrien BIAKAN KUMAN

(NA), 2 jenis kuman pada 6 media spesifik

Setelah dilakukan pemeriksaan terhadap 24 media spesifik di laboratorium Mikrobiologi RSUP Prof. Dr. R. D. Agar Darah (AD) sedangkan 8 media spesifik Agar MacConkey tidak Kandou Manado ditemukan 1 jenis kuman

Tabel 3. Hasil biakan kuman dari udara ruang operasi Instalasi Bedah Sentral RSUP Prof. Dr. R. D. Kandou Manado berdasarkan lokasi dan media spesifik yang digunakan.

\begin{tabular}{|c|c|c|c|c|}
\hline $\begin{array}{l}\text { Sebelum } \\
\text { Operasi }\end{array}$ & Ruang A & Ruang B & Ruang C & Ruang D \\
\hline NA & - & $\begin{array}{c}+ \\
\text { Staphylococcus } \\
\text { albus }\end{array}$ & $\begin{array}{c}+ \\
\text { Staphylococcus } \\
\text { albus }\end{array}$ & - \\
\hline AD & - & $\begin{array}{c}+ \\
\text { Staphylococcus } \\
\text { albus }\end{array}$ & - & $\begin{array}{c}+ \\
\text { Staphylococcus } \\
\text { albus, Bacillus } \\
\text { subtilis }\end{array}$ \\
\hline $\begin{array}{l}\text { MC } \\
\text { Secudah }\end{array}$ & - & - & - & - \\
\hline $\begin{array}{l}\text { Sesudah } \\
\text { Operasi }\end{array}$ & Ruang A & Ruang B & Ruang C & Ruang D \\
\hline NA & $\begin{array}{c}\text { + Staphylococcus } \\
\text { albus }\end{array}$ & $\begin{array}{c}+ \\
\begin{array}{c}\text { Staphylococcus } \\
\text { albus }\end{array}\end{array}$ & $\begin{array}{c}+ \\
\begin{array}{c}\text { Staphylococcus } \\
\text { albus }\end{array}\end{array}$ & - \\
\hline AD & $\begin{array}{c}\text { + Staphylococcus } \\
\text { albus, Bacillus } \\
\text { subtilis }\end{array}$ & $\begin{array}{c}+ \\
\text { Staphylococcus } \\
\text { albus }\end{array}$ & $\begin{array}{c}+ \\
\text { Staphylococcus } \\
\text { albus, Bacillus } \\
\text { subtilis }\end{array}$ & $\begin{array}{c}+ \\
\text { Staphylococcus } \\
\text { albus, Bacillus } \\
\text { subtilis }\end{array}$ \\
\hline MC & - & - & - & - \\
\hline
\end{tabular}

Tabel 4. Persentase kuman di udara ruang operasi IBS

\begin{tabular}{lcc}
\hline Jenis Kuman & $\begin{array}{c}\text { Jumlah } \\
\text { Kuman }\end{array}$ & (\%) \\
\hline Staphylococcus & 11 & 66,6 \\
albus & 4 & 33,4 \\
Bacillus subtilis & 15 & 100 \\
Jumlah &
\end{tabular}

Dari tabel di atas dapat dilihat bahwa kuman yang ditemukan ada 2 jenis. Staphylococcus albus mendominasi 2 media di mana Staphylococcus albus teridentifikasi di media spesifik Agar Nutrien (NA) dan Agar Darah (AD), sedangkan Bacillus subtilis teridentifkasi di media spesifik Agar Darah (AD).

Dari penelitian yang dilakukan di udara pada ruang operasi Instalasi Bedah Sentral (IBS) RSUP Prof. Dr. R. D.
Kandou Manado didapatkan 24 sampel penelitian.Pengambilan sampel dilakukan sesaat sebelum dan sesudah operasi dengan menggunakan 24 media umum dan khusus. Adapun pemeriksaan yang dilakukan terdiri dari isolasi dan identifikasi bakteri aerob di media spesifik Agar Darah (AD), Agar Nutrient (NA), Agar MacConkey (MC) dengan dilakukan pemeriksaan mikroskopi dan pewarnaan gram. Pemeriksaan dilakukan di Laboratorium Mikrobiologi RSUP Prof. Dr. R. D. Kandou Manado.

Pada pemeriksaan yang dilakukan terhadap udara ruang operasi Instalasi Bedah Sentral (IBS) dengan menggunakan 24 sampel media dengan perincian 8 sampel media Agar Nutrient (NA), 8 sampel media Agar Darah (AD), 8 sampel media Agar MacConkey (MC), diperoleh hasil 11 media spesifik menunjukkan 
pertumbuhan kuman, sedangkan 8 sampel media spesifik Agar MacConkey tidak menunjukan pertumbuhan kuman. Dari 11 media spesifik yang menunjukan adanya pertumbuhan kuman ditemukan 2 jenis kuman yaitu Staphylococcus Albus dan Bacillus Subtilisdimana Staphylococcus Albus ditemukan di media spesifik Agar Nutrientt (NA) dan Agar Darah (AD) sedangkan Bacillus Subtilisditemukan di media spesifik Agar Darah (AD).

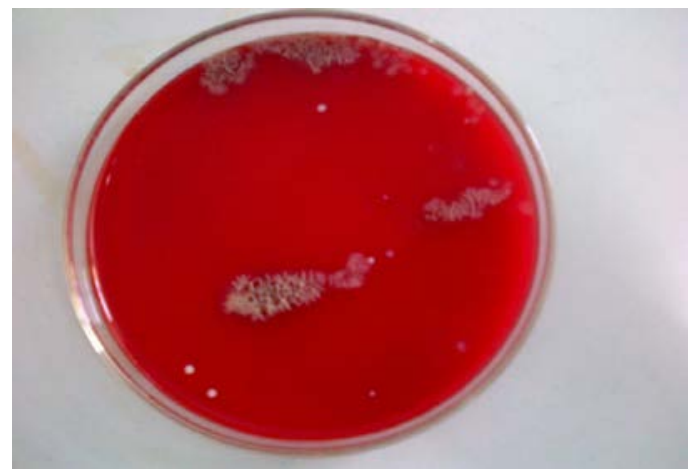

Gambar 3. Bakteri Staphylococcus albus dan Bacillus subtilisdi media spesifik Agar Darah (AD)

Bulan Juli 2009 telah dilakukan penelitian yang sama oleh Waworuntu dengan hasil Staphylococcus Albus sebanding dengan Bacillus Subtilis tetapi pada penelitian tersebut bakteri Staphylococcus Albus hanya ditemukan di media spesifik Nurtrien agar (NA) yang berbanding terbalik dengan penelitian ini dimana Staphylococcus Albus ditemukan juga di media spesifik Agar Darah (AD).

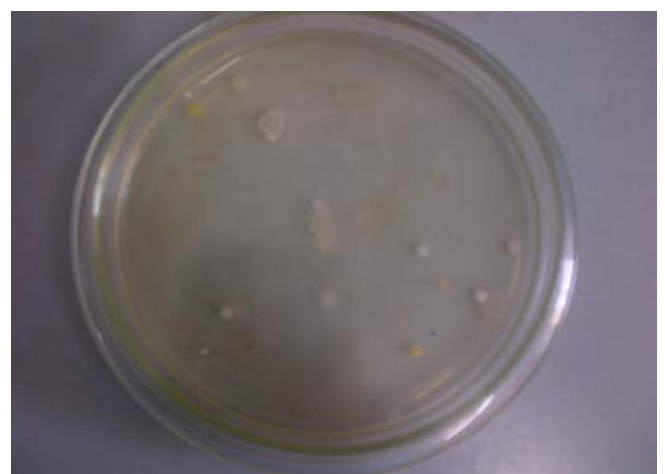

Gambar 4. Bakteri Staphylococcus albus di media spesifik Agar Nutien (NA)

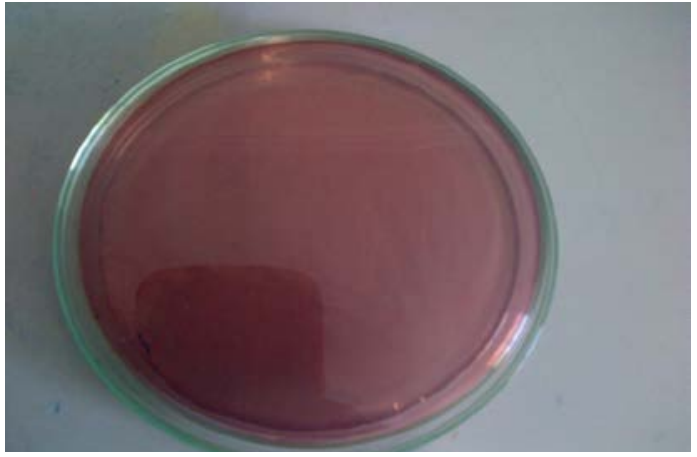

Gambar 5. Media spesifik Agar MacConkey yang tidak mengalami pertumbuhan bakteri

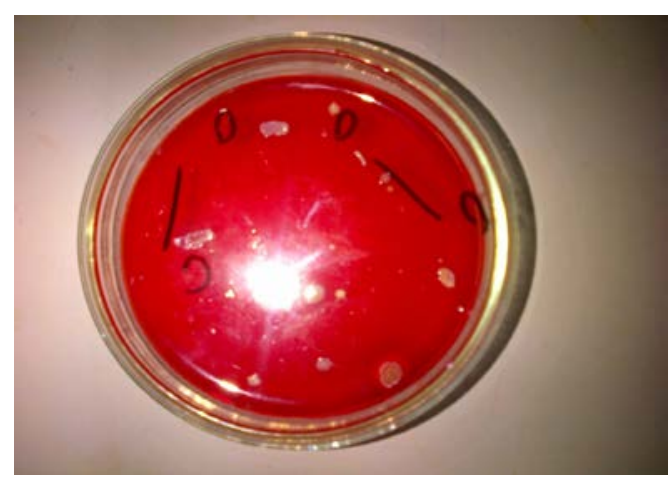

Gambar 6. Bakteri Staphylococcus albus di media spesifik Agar Darah (AD)

Pertumbuhan bakteri lebih meningkat setelah terjadinya operasi. Staphylococcus albus adalah kuman gram positif, bersifat anaerobik fakulatif yang merupakan flora normal pada manusia terdapat pada mukosa hudung, mulut, dan kulit. Terdapat lebih dari 20 spesies Staphylococcus, tapi hanya Staphylococcus aureus dan Staphylococcus albus yangmempunyai hubungan interaksi dengan manusia dimana kolonisasi terutama pada nasal dan kulit.Bakteri ini merupakan penyebab tertinggi infeksi di lingkungan rumah sakit, terutama pada ruangan intensif dan kamar operasi. Penyebarannya sering melalui udara, tetapi dapat juga secara langsung. ${ }^{14,16-18}$

Bacillus subtilis merupakan kuman basil gram positif, bersifat aerobik biasanya didapat dari kontaminasi dengan air, tanah, udara dan residu tanaman.Bakteri ini menghasilkan enzim proteolitik subtilisin dan endospora yang memungkinkan bertahan terhadap suhu tinggi. Enzim yang 
dihasilkan dapat menyebabkan reaksi alergi pada individu yang sering terpapar.Bacillus subtilis bukanlah kuman patogen pada manusia bila dalam jumlah kecil, memiliki toksigenitas rendah seperti genus lainnya dan daya virulensinya rendah. ${ }^{7,14,15,18}$

Hasil penelitian ini menujukan bahwa udara ruang operasi Instalasi Bedah Sentral (IBS) RSUP Prof. Dr. R. D. Kandou Manado masih terkontaminasi mikroorganisme dan ini menunjukan bahwa tingkat sterilisasi yang ada di ruang operasi Intalasi Bedah Sentral (IBS) belum baik sehingga harus ditingkatkan kualitasnya demi terwujudnya pelayanan kesehatan yang baik.

Bakteri yang ditemukan merupakan
jenis bakteri kontaminan udara. Kontaminasi biasanya ditularkan lewat tubuh/tangan, pakaian petugas, dan peralatan yang digunakan di dalam ruang operasi Instalasi Bedah Sentral (IBS).Oleh karena itu sangat perlu dilakukan pemeriksaan berkala dan teratur untuk sterilsasi udara, lingkungan sekitar ruang operasi, petugas dan alat-alat yang digunakan di dalam ruang operasi Instalasi Bedah Sentral (IBS).Hal ini dapat membantu untuk meminimalisasikan kuman yang ada di ruang operasi.

\section{SIMPULAN}

Dari hasil penelitian dapat disimpulkan bahwa di udara ruang operasi Instalasi Bedah Sentral (IBS) RSUP Prof. Dr. R. D. Kandou Manado masih tinggi angka jumlah bakteri aerob yaitu Staphylococcus albus dan Bacillus subtilis. Bakteri yang teridentifikasi di udara ruang operasi Instalasi Bedah Sentral (IBS) RSUP Prof. Dr. R. D. Kandou Manado kemungkinan merupakan jenis bakteri kontaminasi dari tubuh/tangan dan pakaian petugas serta beberapa alat yang digunakan di dalam ruang operasi Intalasi Bedah Sentral (IBS) RSUP Prof. Dr. R. D. Kandou Manado.

\section{DAFTAR PUSTAKA}

1. Supryantoro. Pedoman Teknis Prasarana Sistem Tata Udara pada Bangunan
Rumah Sakit. Kementrian Kesehatan RI Direktorat Bina Pelayanan Penunjang Medik dan Sarana Kesehatan. Jakarta, 2012.

2. Sidqi AN. Pengaruh Dosis Desinfektan terhadap Penurunan Angka Kuman pada Lantai di Ruang Kenanga RSUD Prof. Dr. Margono Soekarjo Purwokerto [Skripsi]. Semarang: Politeknik Kesehatan; 2011.

3. Adam S. Pedoman Teknis Ruang Operasi Rumah Sakit. Jakarta: Kementrian Kesehatan RI Direktorat Jendral Bina Upaya Kesehatan, 2010.

4. Utji R. Pengendalian Infeksi Nosokomial di RS Dr. Cipto Mangunkusumo dengan Sumber Daya Minimal [Skripsi]. Jakarta: Universitas Indonesia; 2008.

5. Mertaniasih NM. Pengalaman Monitoring Hygiene Kamar Operasi. Jakarta: Perhimpunan Ahli Mikrobiologi Klinik Indonesia (PAMKI), 2003.

6. Adji D, Zuliyanti, Larashanty $H$. Perbandingan Efektivitas Sterilisasi Alkohol 70\%, Inframerah, Otoklaf dan Ozon terhadap Pertumbuhan Bakteri Bacillus subtilis. Yogyakarta: Universitas Gadjah Mada; 2007.

7. Kariasih IM. Peran Perilaku Dalam Mencegah Infeksi Nosokomial. Jakarta: Perhimpunan Ahli Mikrobiologi Klinik Indonesia (PAMKI), 2003.

8. Sampurna B. Aspek Hukum Infeksi Nosokomial. Jakarta: Perhimpunan Ahli Mikrobiologi Klinik Indonesia (PAMKI), 2003.

9. Nicols RL. Infeksi Bedah dan Pemilihan Anti Biotika. Sabiston, Buku ajar Bedah (Essential of Surgery) (1st ed). Jakarta: EGC, 1995; p. 176-8.

10.Raihana N. Profil dan Kultur Uji Sensifitas Bakteri Aerob dari Infeksi Luka Operasi Laparatomi di bangsal Bedah RSUP DR. M. Djamil Padang [Skripsi]. Padang: Universitas Andalas; 2010.

11.Walyono L. Mikrobiologi Umum. Edisi Revisi: Universitas Muhammadiyah. 2007. Hal. 148 dan 308.

12.Entjang I. Mikrobiologi dan Parasitologi. Bandung: PT. Citra Aditya Bakti, 2003; p. 54-7.

13.Irianto K. Menguak Dunia Mikrobiologi Jilid 2. Bandung: CV. Yrama Widya, 
2007; p. 156.

14.Jawetz, Melnick, \& Adelberg. Mikrobiologi Kedokteran (23rd ed). Jakarta: EGC, 2004; p. 152, 153, 204325.

15.Gillespie \& Bamfrod. At a Glance Mikrobiologi Medis dan Infeksi (3rd ed). Jakarta: Erlangga, 2009; p. 12, 13.

16.Tanjung M. Pola Kuman di Kamar Operasi dan Ruang Perawatan Bedah RSUP Prof. Dr. R. D. Kandou Manado
[Tesis]. Manado: Universitas Sam Ratulangi; 2010.

17.Suripatty N. Kajian kualitas udara ruang rumah sakit di Provinsi Maluku [Skripsi]. Ambon: Politeknik Kesehatan; 2008.

18.Tangkuman IN. Methicillin Resistant Staphylococcus aureus (MRSA) pada Infeksi Luka Operasi [Tesis]. Manado: Universitas Sam Ratulangi; 2011. 